\title{
Root Development of Rhizophora apiculata Seedlings Under Extremely Low Oxygen Concentration of the Soils
}

\author{
Vipak JINTANA United Graduate School of Agricultural Sciences, Ehime University, Matsuyama 790, JAPAN \\ Ikuo NINOMIYA College of Agriculture, Ehime University, Matsuyama 790, JAPAN \\ Kazuhiko OgINo College of Agriculture, Ehime University, Matsuyama 790, JAPAN
}

\begin{abstract}
The root development of Rhizophora apiculata seedling under extremely low oxygen of the soil was contrasted with that under normal concentration. A young seedling grown in a pot of $10.7 \mathrm{~cm}$ in diameter and $42 \mathrm{~cm}$ in height was treated either unaerated or aerated condition in greenhouse. Each pot was flooded with Hoagland's nutrient solution to the upper tip. The oxygen concentration of the soil at 15 $\mathrm{cm}$ depth was found to have kept at the level below $0.6 \mathrm{mg} \mathrm{l}^{-1}$ under unaerated, between 2.2 and $2.5 \mathrm{mg} \mathrm{l}^{-1}$ under aerated treatment. The seedlings were sampled after 85 and 115 days of treatments to examine root length, number of the main and lateral root, and dry weight. It was disclosed that biomass, vertical distribution and elongation rate of the root remarkably decreased, and number of lateral root sharply increased. Although, T/R ratio showed no difference between the treatments, the proportion of fine roots increased. Intercellular space in the root cortex was found also increasing. It was concluded that the lower oxygen concentration of the soil caused the morphological and anatomical deformation of the $R$. apiculata seedlings.
\end{abstract}

Key Words: mangrove / Rhizophora apiculata / T/R ratio / root development / aerobic / anaerobic

Mangrove trees grow under highly stressed conditions, as high salinity, and low oxygen supply in the substratum. A large number of researchers as summarized by Lugo et al. (1981) have studied the responses of mangroves to high salinity and concentrated nutrient solutions, high (and low) temperature. The responses of Avicennia marina seedlings to the different oxidation-reduction conditions of soils on root development was recently investigated (Toma et al., 1991).

Root biomass of the mangrove forests have been reported to be greater than shoot biomass (Briggs, 1977; Golley et al.,1962; Golley et al.,1962; Lugo \& Snedaker, 1974; Ogino et al.,1986). The substratum in which the roots are embedded is generally anaerobic or poor in oxygen. Mangroves develop their root systems in accordance with their aeration requirement (Saenger, 1982). The stilt roots in Rhizophora and air roots in Avicennia were found essential aeration system for ventilation of under ground root system (Curran et al., 1986; Scholander et al., 1955; Toma et al., 1991). Apparently the aerenchyma of mangrove roots were found to contain high oxygen concentration to permit aerobic respiration to the tissues (Chapman, 1976).

Toma (1992, personal communication) found that oxygen concentration of mangrove soil solution varied from place to place. The variation may be attributable to the topographic position, geographic location and other biological factors of the forest (Lugo et al., 1981). The 
influences of varying oxygen concentration on root growth, morphological and anatomical structure of Rhizophora apiculata seedling were investigated. The experimental study was designed to analyze potential adaptive mechanisms of Rhizophora apiculata seedling grown under insufficient oxygen concentration of the soil.

\section{MATERIAL AND METHOD}

Ten Rhizophora apiculata seedlings were planted on June 18, 1990. The other ten seedlings were planted on January 25,1991 . Those seedlings were grown individually in plastic cylindrical pots $10.7 \mathrm{~cm}$ in diameter and $42 \mathrm{~cm}$ in height under greenhouse conditions as described by Jintana et al. (1991). The pots were filled with 2:1 (v/v) mixture of sand and leaf compost up to $10 \mathrm{~cm}$ below the edge. The substratum was flooded with Hoagland's solution up to the edge of the pots. Flooding were kept until April 15, 1991 (301 and 80 days old seedlings). The 80 days old seedlings flushed their first pair of leaves. Ten additional hypocotyls were planted ( 0 day old seedlings). The substratum of each pot was treated either aerated condition or unaerated. The aeration was performed with Air Pumps (Chikara Alpha 1000) (Fig. 1). To avoid shaking the soil the rate of air flow was kept at $7 \mathrm{ml} \mathrm{s}^{-1}$ by a control valve. The pots under unaerated condition were kept flood without aeration. Nutrient solution was added daily to maintain the level to the top of the pot.

The soil solution was examined every two days during the first 10 days after treatment and later it was measured once a week regularly. Water samples of each treatment were taken from the surface (floodwater) and at $15 \mathrm{~cm}$ depth of six pots. DO (dissolved oxygen), EC, $\mathrm{pH}$ and Eh were measured with TOA portable DO meter (DO-11P), an electric conductivity meter (CM-11P), glass electrode $\mathrm{pH}$ meter (RM-10P) and Redox potential meter (HM10P/HM-11P), respectively.

The net photosynthetic rate during daytime and the rate of respiration during nighttime were measured with a portable gas analyzer (Model LCA-2) on July 9, 1991. Four uppermost fully expanded leaves were selected for the measurement. The photosynthetic rate was measured under light-saturation at photon flux density of about $600 \mu \mathrm{mole} \mathrm{sec}^{-1} \mathrm{~m}^{-2}$ (NRCT, 1991). The seedlings were pre-treated in a light-controlled-chamber for $30 \mathrm{~min}$ before the measurement. The leaf chamber enclosed a leaf area of $6.25 \mathrm{~cm}^{2}$. The respiration of the same

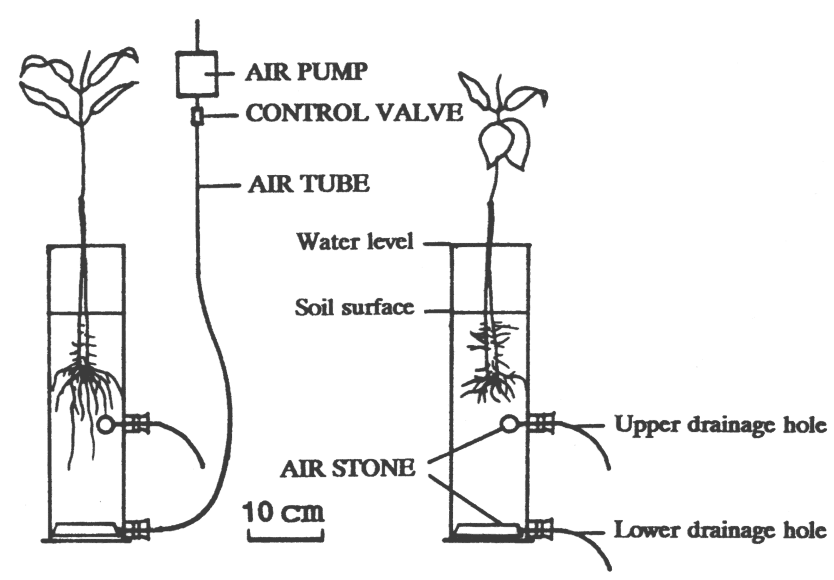

Fig. 1. Scheme of cultivation pot with the aerated (left) and the unaerated (right) treatments. 
leaves were measured at night of the same day. All measurements were carried out in triplicate. One day later ten seedlings were sampled for shoot and root measurements. Stem diameters were measured at the first node (the top of hypocotyl). Stem heights were measured from the first node to the base of shoot apex. The numbers of leaves and nodes were recorded. The midday leaf water potential(WP) were measured by a pressure-chamber (PMS, Model 1020). The pressure at the first appearance of sap from the cut surface of the shoot, as observed with a hand lens, was taken as leaf water potential. Leaf area of the plants was determined with an MK2 Area Meter. The seedlings were carefully rinsed, separated into roots and shoots. Numbers and length of the main roots, numbers of lateral roots per $\mathrm{cm}$ along the main root were examined. To calculate rates of root elongation, total length of the main roots at 0,85 , 135 (data from Vipak et al., 1991), 195 and 416 days of individual seedlings grown in unaerated soils were analyzed. The mean total lengths of the main roots just before treatments were estimated. The average rates of root elongation under treatments were calculated.

Roots were stratified by $5 \mathrm{~cm}$ layers from soil surface. All the roots in each layer were sorted into diameter classes (0-1, 1-2, 2-5 and 5-10 mm). All samples were dried at $80^{\circ} \mathrm{C}$ for $48 \mathrm{~h}$ to determine dry weight (Moog \& Janiesch, 1990). Root density was calculated for each layer (Komiyama et al., 1987). The seedlings those planted on June 18, 1990 and January 25, 1991 were measured the photosynthesis and respiration on August 7, 1991 and uprooted for root study on August 8, 1991 (115 days after treatment).

Transection at $2 \mathrm{~cm}$ above root tips were observed with a photomicroscope (Nikon AFXIIA). The number of cell layers of multiple epidermis and cortex were counted and the intercellular space of the cortex were calculated using an MK2 Area Meter by mapping its crosssectional relative area.

\section{Soil conditions}

\section{RESULTS}

Soil conditions under treatments are shown in Table 1. Aeration of the flooded soil resulted in greater dissolved oxygen in the deeper layers. The DO value at $15 \mathrm{~cm}$ depth was up to 2.24-2.

Table 1. Properties of soil solution in the aerated and the unaerated pots. Data represent mean values \pm standard deviation; $P$-values (F-test) $<0.05\left(^{*}\right),<0.01\left(^{+}\right)$.

\begin{tabular}{|c|c|c|c|c|c|}
\hline Treatment & $\begin{array}{l}\text { Depth } \\
(\mathrm{cm})\end{array}$ & $\begin{array}{l}\mathrm{DO} \\
\left(\mathrm{mg} \mathrm{l}^{-1}\right)\end{array}$ & $\begin{array}{l}\text { Eh } \\
(\mathrm{mV})\end{array}$ & $\mathrm{pH}$ & $\begin{array}{c}\mathrm{EC} \\
\left(\mathrm{mS} \mathrm{cm}^{-1}\right)\end{array}$ \\
\hline $\begin{array}{l}\text { Aerated }^{\mathrm{a}} \\
\text { Unaerated }\end{array}$ & $\begin{array}{l}\text { surface } \\
15 \\
\text { surface } \\
15\end{array}$ & $\begin{array}{l}4.96 \pm 0.35 \\
2.24 \pm 0.55 \\
2.66^{\dagger} \pm 0.70 \\
0.56^{\dagger} \pm 0.11\end{array}$ & $\begin{array}{l}383 \pm 35 \\
357 \pm 28 \\
361 \pm 54 \\
349 \pm 33\end{array}$ & $\begin{array}{l}7.53 \pm 0.39 \\
7.30 \pm 0.21 \\
7.74 \pm 0.36 \\
6.88^{\dagger} \pm 0.10\end{array}$ & $\begin{array}{l}1.253 \pm 0.087 \\
1.073 \pm 0.072 \\
1.567^{+} \pm 0.103 \\
1.287^{+} \pm 0.158\end{array}$ \\
\hline $\begin{array}{l}\text { Aerated } \\
\text { Unaerated }\end{array}$ & $\begin{array}{l}\text { surface } \\
15 \\
\text { l surface } \\
15\end{array}$ & $\begin{array}{l}4.70 \pm 1.14 \\
2.51 \pm 0.84 \\
7.96^{\dagger} \pm 2.63 \\
0.21^{\dagger} \pm 0.08\end{array}$ & $\begin{array}{l}356 \pm 33 \\
357 \pm 31 \\
339 \pm 37 \\
313^{+} \pm 36\end{array}$ & $\begin{array}{l}7.90 \pm 0.25 \\
7.41 \pm 0.15 \\
8.30^{*} \pm 0.41 \\
6.84^{+} \pm 0.12\end{array}$ & $\begin{array}{l}1.459 \pm 0.112 \\
1.297 \pm 0.058 \\
1.758^{\dagger} \pm 0.094 \\
2.014^{+} \pm 0.206\end{array}$ \\
\hline $\begin{array}{l}\text { Aerated } \\
\text { Unaerated }\end{array}$ & $\begin{array}{l}\text { surface } \\
15 \\
\text { surface } \\
15 \\
\end{array}$ & $\begin{array}{l}4.74 \pm 1.13 \\
2.24 \pm 0.97 \\
5.56 \pm 2.10 \\
0.16^{\dagger} \pm 0.02 \\
\end{array}$ & $\begin{array}{l}376 \pm 51 \\
348 \pm 25 \\
358 \pm 30 \\
290^{+} \pm 35\end{array}$ & $\begin{array}{l}7.63 \pm 0.22 \\
7.59 \pm 0.08 \\
7.68 \pm 0.23 \\
7.02^{\dagger} \pm 0.14 \\
\end{array}$ & $\begin{array}{l}1.846 \pm 0.201 \\
1.297 \pm 0.058 \\
1.653^{*} \pm 0.084 \\
2.227^{+} \pm 0.138 \\
\end{array}$ \\
\hline
\end{tabular}

Key to symbols: DO, dissolved oxygen; Eh, redox potential; EC, electrical conductivity; a, aeration started on the same day of planting (April 15,1991); b, aeration started 80 days after planting; c, aeration started 301 days after planting. 
Table 2. The rates of net daytime photosynthesis, nighttime respiration, and leaf water potential of Rhizophora apiculata seedlings grown under the aerated and the unaerated conditions. Data represent mean values \pm standard deviation; P-values (F-test) $<0.05\left(^{*}\right),<0.01\left(^{+}\right)$; super script as in Table 1.

\begin{tabular}{lccc}
\hline & $\begin{array}{c}\text { Net } \\
\text { photosynthesis } \\
\left(\mathrm{mgCO}_{2} \mathrm{dm}^{-2} \mathrm{~h}^{-1}\right)\end{array}$ & $\begin{array}{c}\text { Nighttime } \\
\text { respiration } \\
\left(\mathrm{mgCO}_{2} \mathrm{dm}^{-2} \mathrm{~h}^{-1}\right)\end{array}$ & $\begin{array}{c}\text { Leaf } \\
\text { water potential } \\
(\text { bars })\end{array}$ \\
\hline $\begin{array}{l}\text { 85 days old } \\
\text { Aerated }\end{array}$ & $19.90 \pm 3.47$ & $1.58 \pm 0.20$ & $-23.8 \pm 1.2$ \\
$\begin{array}{l}\text { Unaerated } \\
\text { 195 days old }\end{array}$ & $21.77 \pm 3.46$ & $1.68 \pm 0.12$ & $-25.5 \pm 4.2$ \\
$\begin{array}{l}\text { Aerated } \\
\text { Unaerated }\end{array}$ & $14.26 \pm 2.37$ & $1.46 \pm 0.12$ & $-14.6 \pm 1.5$ \\
$\begin{array}{l}\text { 416 days old } \\
\text { Aeratedc }\end{array}$ & $18.11^{\dagger} \pm 3.44$ & $1.57 \pm 0.04$ & $-18.5 \pm 2.4$ \\
Unaerated & $12.88 \pm 4.43$ & $1.58 \pm 0.33$ & $-15.3 \pm 0.7$ \\
\hline
\end{tabular}

Table 3. Biomass of Rhizophora apiculata seedlings after 85 and 115 days of growth under the aerated and the unaerated conditions. Data represent mean values \pm standard deviation; P-values (F-test) $<0.05\left(^{*}\right),<0.01\left(^{\dagger}\right)$; super script as in Table 1.

\begin{tabular}{|c|c|c|c|c|c|c|}
\hline & & & ry weight ( $g$ & seedling $^{-1}$ ) & & \\
\hline & 85 days ol & d seedlings & 195 days old & seedlings & 416 days ol & ld seedlings \\
\hline & Aerated ${ }^{\mathrm{a}}$ & Unaerated & Aerated $^{\mathrm{b}}$ & Unaerated & Aerated $^{c}$ & Unaerated \\
\hline Hypoco & $9.16 \pm 0.49$ & $7.22 \pm 0.94$ & $10.32 \pm 0.56$ & $10.83 \pm 0.16$ & $17.40 \pm 3.40$ & $16.79 \pm 1.77$ \\
\hline Shoot (T) & $1.59 \pm 0.13$ & $0.98^{\dagger} \pm 0.13$ & $5.77 \pm 0.63$ & $4.29^{\dagger} \pm 0.46$ & $42.79 \pm 5.95$ & $26.40^{\dagger} \pm 1.57$ \\
\hline Root (R) & $0.47 \pm 0.03$ & $0.33^{\dagger} \pm 0.04$ & $1.22 \pm 0.38$ & $1.02 \pm 0.11$ & $11.44 \pm 0.65$ & $10.84 \pm 0.77$ \\
\hline$T / R$ ratio & 3.40 & 3.00 & 5.21 & 4.29 & 3.76 & 2.45 \\
\hline
\end{tabular}

$51 \mathrm{mg} \mathrm{l}^{-1}$ whereas in the unaerated soils it dropped to less than $0.56 \mathrm{mg} \mathrm{l}^{-1}(\mathrm{P}<0.01)$. The redox potential was slightly oxidative in aerated pots. The Eh values of surface water and at $15 \mathrm{~cm}$ depth were greater in the aerated. The $\mathrm{pH}$ values of the aerated and the unaerated showed the similar values, the lower the value, the deeper the layer. The EC, electric conductivity of the unaerated soils increased with the depth.

\section{Growth performance}

In the unaerated condition, growth of seedlings were smaller than those grown under the aerated soils (Table 3 ). The shoot dry weight decreased by $26-38 \%$ and root by $5-30 \%$ as comparison with in the aerated. The shoot to root (T/R) ratio was, however, not significantly affected by the treatment.

Table 2 shows the net photosynthetic rate at photon flux density of $592 \pm 13 \mu \mathrm{mole} \mathrm{sec}^{-}$ ${ }^{1} \mathrm{~m}^{-2}$. The higher rate was observed in the unaerated. Dark respiration rate showed no remarkable difference between the treatment. Whereas, the midday leaf water potential of the seedlings in the unaerated were lower than those in the aerated. This may be due to the decrease of absorbing roots in the unaerated.

\section{Root development}

In the unaerated condition the seedlings produced a greater number of the main and lateral roots $(\mathrm{P}<0.05)$. But the total and average length of the main roots were shorter (Table 4$)$. 
Root density [mg cm $\mathrm{seedling}^{-1}$ ] Root density [ $\mathrm{mg} \mathrm{cm}^{-3}$ seedling ${ }^{-1}$ ]
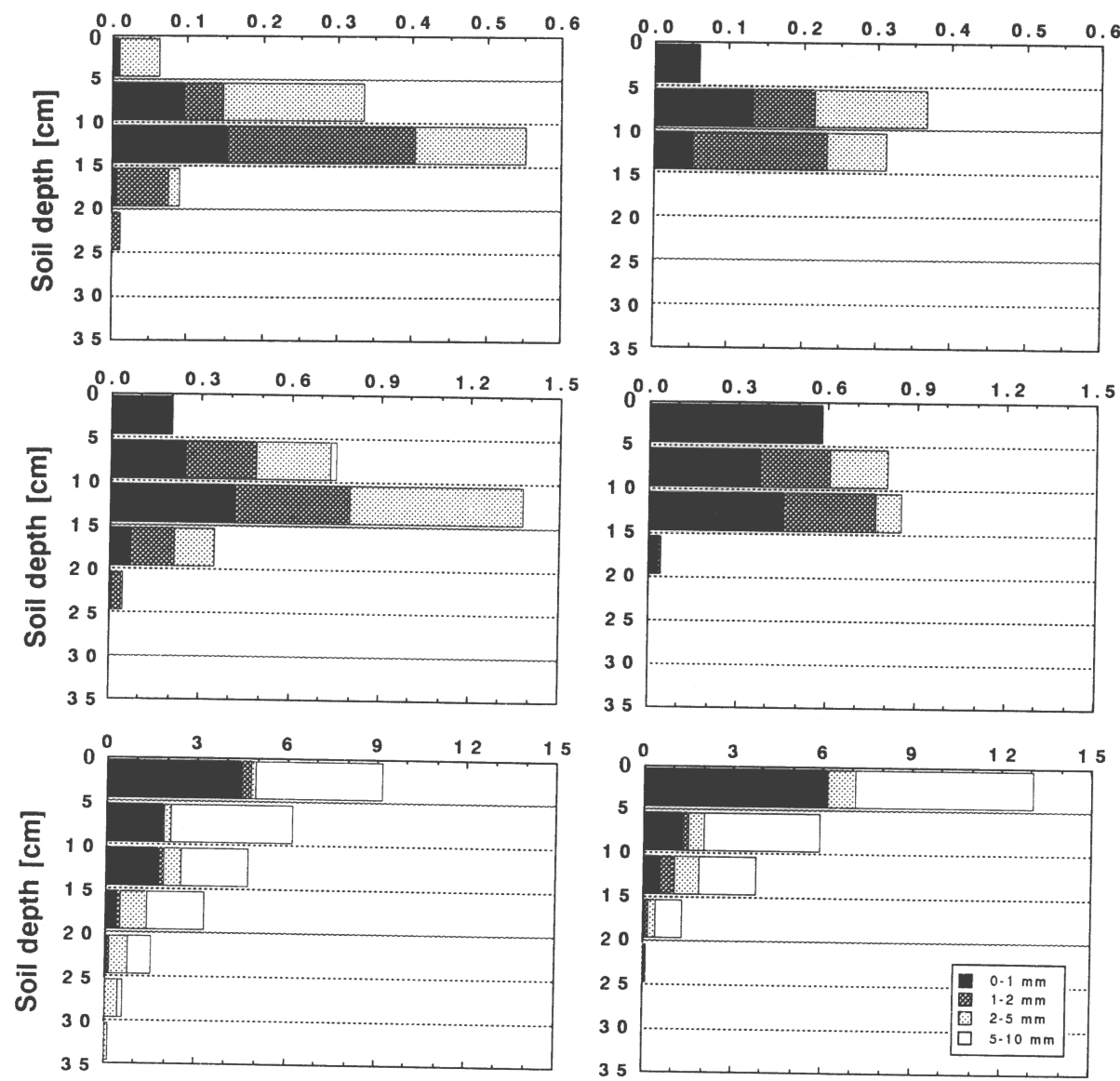

Fig. 2. Vertical distribution of root density of Rhizophora apiculata seedlings grown under the aerated (left) and the unaerated (right) conditions. Above, 85 days old; middle, 195 days old; below, 416 days old.

Vertical distribution of root density of the seedlings under treatments are shown in Fig. 2. In the aerated condition, the roots penetrated into the deeper soil layers. In the unaerated many roots developed close to the surface. More than a half of the total root, especially the fineroots, distributed within the upper $10 \mathrm{~cm}$. In the aerated the roots distributed near the soil surface were found only in the 416 days old seedlings. And the root systems had developed before the treatment was first introduced. The size distribution of the roots showed no remarkable difference between the treatment (Table 4).

As shown in Fig. 3 the root lengths of the seedlings were plotted against the age (0-416 days old) grown in the unaerated condition. Assuming that the lengthwise growth of the roots followed the following equation, the mean total root lengths of seedlings $(L)$ before the treatments were calculated $\left(\mathrm{R}^{2}=0.8212\right)$.

$$
\begin{array}{r}
L=1.31606 T \\
\mathrm{r}=0.9844
\end{array}
$$

where $T$ stands for number of days after planting, ' $r$ ' for the correlation coefficient. The 
Table 4. Morphological characteristics of the roots of Rhizophora apiculata seedlings after 85 and 115 days of growth under the aerated and the unaerated conditions. Average values of 5 samples; P-values (F-test) $<0.05\left(^{*}\right),<0.01\left(^{+}\right)$.

\begin{tabular}{|c|c|c|c|c|c|c|}
\hline & \multicolumn{2}{|c|}{85 days old seedlings } & \multicolumn{2}{|c|}{195 days old seedlings } & \multicolumn{2}{|c|}{416 days old seedlings } \\
\hline & Aerated $^{a}$ & Unaerated & Aerated $^{\mathrm{b}}$ & Unaerated & Aerated $^{c}$ & Unaerated \\
\hline $\begin{array}{l}\text { Proportion of root bion } \\
10 \mathrm{~cm} \text { depth }(\%)\end{array}$ & $\begin{array}{l}\text { mass abov } \\
\quad 37\end{array}$ & $59^{*}$ & 35 & $62^{+}$ & 60 & $79^{+}$ \\
\hline $\begin{array}{l}\text { Proportion in weight } \\
\text { of fine-roots }(\%)\end{array}$ & 62 & 68 & 64 & 87 & 36 & 37 \\
\hline $\begin{array}{l}\text { Number of the } \\
\text { main roots }\end{array}$ & 21 & $29^{*}$ & 28 & $47^{*}$ & 57 & $71^{+}$ \\
\hline $\begin{array}{l}\text { Total root } \\
\text { length }(\mathrm{cm})\end{array}$ & 109 & $73^{*}$ & 296 & 246 & 597 & 584 \\
\hline $\begin{array}{l}\text { Average root } \\
\text { length }(\mathrm{cm})\end{array}$ & 5.2 & $2.5^{*}$ & 10.6 & $5.2^{\dagger}$ & 10.8 & $8.1^{*}$ \\
\hline $\begin{array}{l}\text { Rate of root elongation } \\
\qquad\left(\mathrm{mm} \mathrm{d}^{-1} \text { root }^{-1}\right)\end{array}$ & 0.6 & $0.3^{\dagger}$ & 0.6 & $0.3^{+}$ & 0.3 & $0.2^{*}$ \\
\hline $\begin{array}{l}\text { Number of laterals } \\
\text { per cm main root }\end{array}$ & 9 & $15^{*}$ & 11 & $21^{*}$ & 14 & $22^{+}$ \\
\hline $\begin{array}{l}\text { Maximum root } \\
\text { depth }(\mathrm{cm})\end{array}$ & 20 & $15^{+}$ & 25 & $20^{+}$ & 35 & $25^{+}$ \\
\hline $\begin{array}{l}\text { Number of epidermal } \\
\text { cell layers }\end{array}$ & 3 & 3 & 4 & 4 & 4 & 4 \\
\hline $\begin{array}{l}\text { Number of } \\
\text { cortical cell layers }\end{array}$ & 14 & 14 & 18 & 18 & 18 & 18 \\
\hline $\begin{array}{l}\text { Intercellular space } \\
\text { of the cortex }(\%)\end{array}$ & 22 & $30^{*}$ & 27 & 32 & 27 & 33 \\
\hline
\end{tabular}

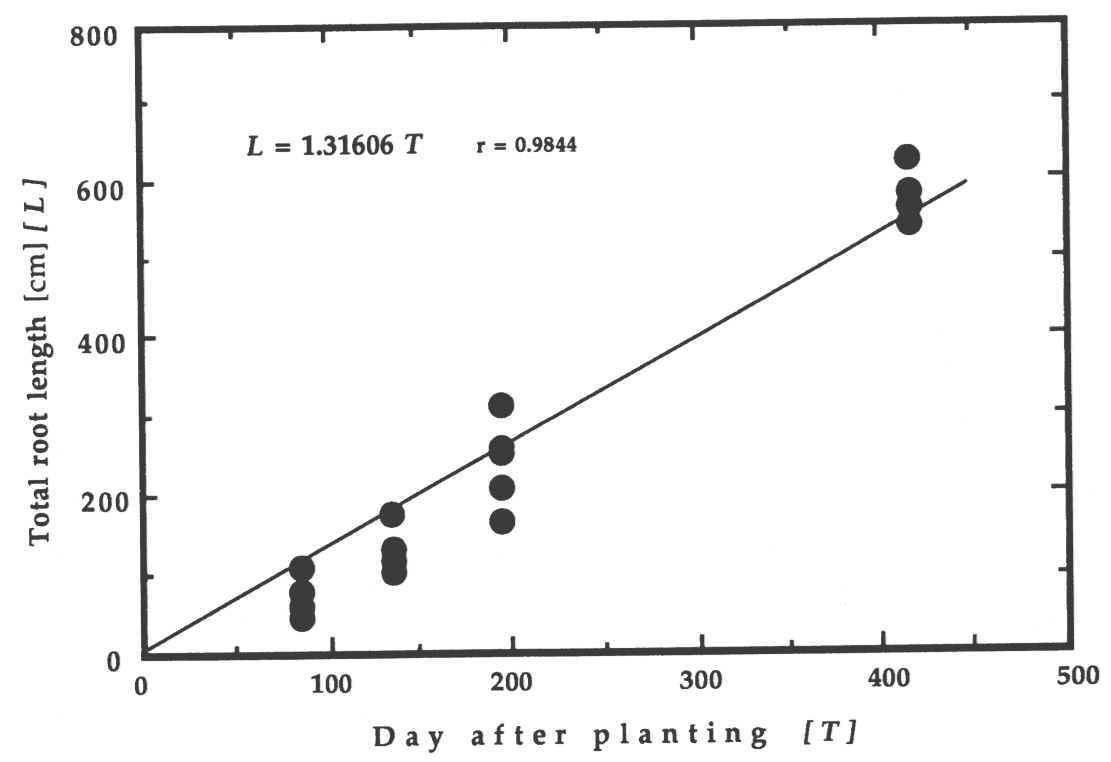

Fig. 3. Growth of the main root length of Rhizophora apiculata seedlings under the unaerated condition. 


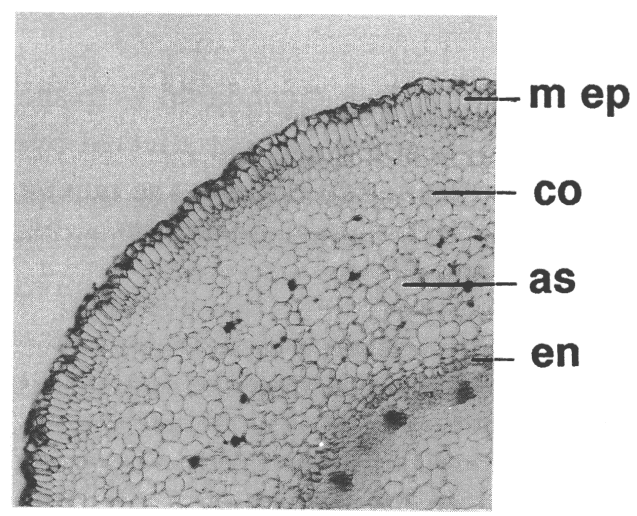

$100 \mu \mathrm{m}$

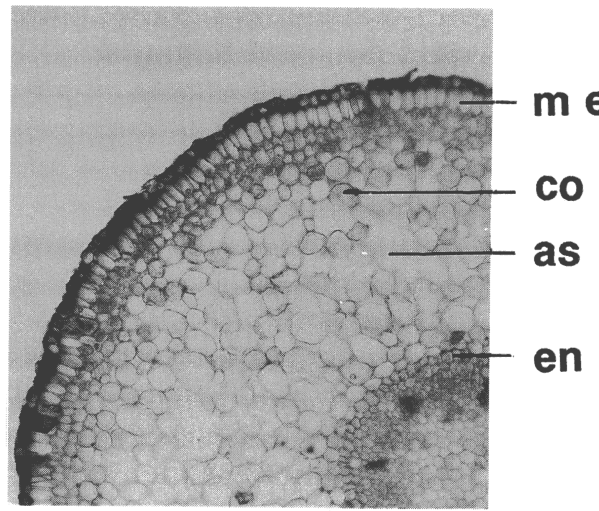

$100 \mu \mathrm{m}$

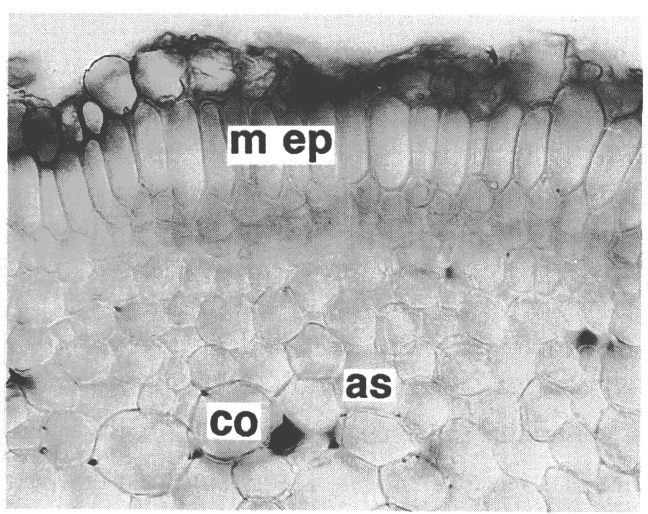

$100 \mu \mathrm{m}$

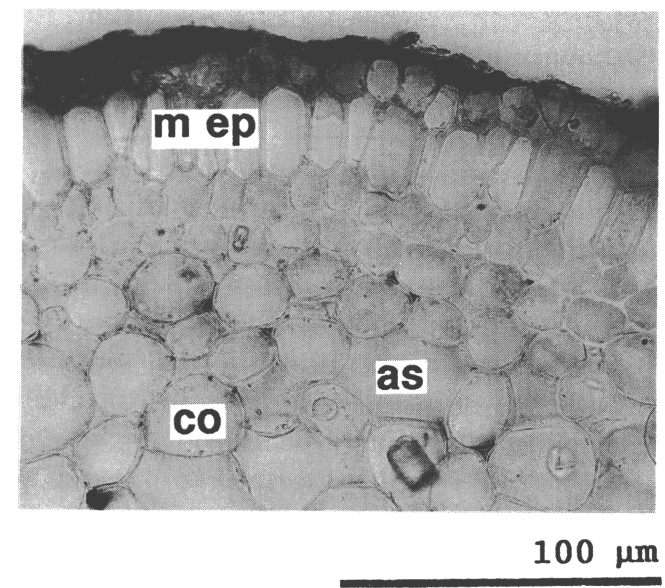

Fig. 4. Cross-sections of roots of Rhizophora apiculata seedlings grown under the aerated (above) and the unaerated (below) conditions: $\mathrm{m}$ ep, multiple epidermis; co, cortex; as, air space; en, endodermis.

average rate of root elongation of the seedlings under the treatments were therefore determined as shown in Table 4.

In the aerated condition the average root elongation of all ages were relatively faster than in the unaerated. This may indicate the higher oxygen concentration in a soil enhance the root elongation.

\section{Root anatomy}

The roots were examined their anatomical structure under the light-microscope. The cross section was consisted of 3-4 layers of multiple epidermis and thick (14-18 layers) cortex with large intercellular spaces. The spaces or air-filled channels in the cortex was observed larger in the unaerated (Fig. 4).

\section{DISCUSSION}

Table 1 shows the aeration brought about higher oxygen concentration in the treated soils. Whereas in the unaerated treatment the soil was rendered practically low oxygen. The oxygen 
of flood water was relatively high because the water body was exposed to the atmosphere (Toma, et al., 1991).

The responses of Rhizophora apiculata seedlings to the anaerobic condition were shown by a reduction of root and shoot biomass (Table 3 ). The T/R ratio was not affected by the treatments. Vertical distribution of the roots were apparently affected (Fig 2). The maximum root depth were significantly shallow $(\mathrm{P}<0.01)$ in the anaerobic condition (Fig 2 and Table 4). Amstrong and Boatman (1967) found that in stagnant, anaerobic substrate, the main roots of Molinia caerulea were restricted to the upper $5 \mathrm{~cm}$ with upward-growing laterals. Menyanthes trifoliata and Narthecium spp. penetrated only $10 \mathrm{~cm}$ depth. The vertical distribution of the plant roots could be attributable to the escape of the root systems from the layer where oxygen deficiency was severest (Alberda, 1953).

A large number of lateral roots produced on the main roots resulted in an increase of fineroots. The number of lateral roots per $\mathrm{cm}$ of the main roots were significantly greater $(\mathrm{P}<0$. 05 ) in the unaerated condition (Table 4). Tabuchi et al. (1983) found that the amount of fineroots (roots with diameter less than $2 \mathrm{~mm}$ ) of mangrove forest in southern Thailand shared a surprisingly high percentage (72\%) of the total root dry weight. Sena and Kozlowski (1980) reported that the formation of adventitious fine-roots was an important adaptation for flood tolerant species as shown by the high efficiency of fine-roots in water absorption and in high correlation between the production of fine-roots and stomatal reopening.

The short average root length, the slow rate of root elongation, and the large air spaces in root cortex under low oxygen concentration (Table 4) were consistent characteristics with what was reported by Rendig \& Taylor (1989). The root systems responded to waterlogged soils by increasing their internal porosity through development of large continuous air-filled channels, aerenchyma. These channels would contribute to the gaseous diffusion toward the root tips (Curran et al., 1986; Scholander et al., 1955).

In conclusion, the low oxygen supply in the rhizosphere caused the inhibition of the growth performance of Rhizophora apiculata seedlings. Morphological and anatomical structure changed under the anaerobic conditions. The change seems to show the adaptive capability of $R$. apiculata to lower oxygen concentration of the rhizosphere. The shift of vertical distribution, the short length of the total root, the development of the lateral-fine-roots, and the enhanced air-filled channel formation showed the possible adaptive mechanisms of seedlings in accordance with the oxygen requirement of their root systems.

ACKNOWLEDGMENTS The authors are deeply in dept to Dr. Marta Vannucci, Vice President of International Society for Mangrove Ecosystems (ISME), Professor Dr. Sanit Aksornkoae of Kasetsart University, Dr. Jitt Kongsangchai of Royal Forest Department, and Associate Professor Dr. Akira Komiyama of Gifu University. Their guidance, and constant encouragement throughout are highly appreciated. The seed material used in the present study was kindly provided by Mr. Nirat Jintana and Mr. Tanuwong Sangtiean, the Royal Forest Department of Thailand.

\section{REFERENCES}

Alberda, T. 1953. Growth and root development of lowland rice and its relation to oxygen supply. Plant and Soil 5: 1-28.

Amstrong, W. \& Boatman, D. J. 1967. Some field observations relating the growth of bog 
plants to conditions of soil aeration. Journal of Ecology 55: 101-110.

Briggs, S. V. 1977. Estimates of biomass in a temperate mangrove community. Australian Journal of Ecology 2: 369-373.

Chapman, V. J. 1976. Mangrove Vegetation, 447 pp. Cramer, Lehre.

Curran, M., Cole, M. \& Allaway, W. G. 1986. Root aeration and respiration in young mangrove plants (Avicennia marina (Forsk.) Vierh.). Journal of Experimental Botany 37 (181): 1225-1233.

Jintana, V., Toma, T., Ninomiya, I. \& Ogino, K. 1991. Root Development of Rhizophora apiculata seedlings under different aerated condition. The 102 th Ann. Meet. of Jap. For. Soc.: 555-556. (in Japanese)

Golley, F. B., Odum, H. T. \& Wilson, R. F. 1962. The structure and metabolism of a Puerto Rico red mangrove forest in May. Ecology 70: 649-666.

Golley, F. B., McGinnis, J. T., Clements, R. G., Child, G. I. \& Duever, M. J. 1975. Mineral Cycling in a Tropical Moist Forest Ecosystem, 248 pp. University of Georgia Press, Athen.

Komiyama, A., Ogino, K., Aksornkoae, S. \& Sabhasri, S. 1987. Root biomass of a mangrove forest in southern Thailand. 1. Estimation by the trench method and the zonal structure of root biomass. Journal of Tropical Ecology 3: 97-108.

Lugo, A. E., Cintron, G. \& Goenaga, C. 1981. Mangrove ecosystems under stress. In: Barrett, G. W. \& Roseenberg R. (eds.), Stress Effects on Natural Ecosystems, 129-153. John Wiley \& Sons Ltd.

Lugo, A. E. \& Snedaker, S. C. 1974. The ecology of mangroves. Annual Review of Ecology and Systematics 5: 39-64.

Moog, P. R. and Janiesch, P. 1990. Root growth and morphology of Carex species as influenced by oxygen deficiency. Functional Ecology 4: 201-208.

NRCT. 1991. The integrated multidisplinary survey and research programme of the Ranong mangrove ecosystem. Final Report of the UNESCOIUNDP Regional Project-Research and its Application to the Management of Mangroves of Asia and the Pacific (RAS/86/120), 183 pp. Bangkok.

Ogino, K., Nakasuga, T., Tamai, S., Komiyama, A., Aksornkoae, S. \& Sabhasri, S. 1986. Biomass studies of mangrove forest in southern Thailand. In: Soemodihardjo, S. (ed.), Proceedings of MAB-COMAR Regional Workshop on Coral Reef Ecosystems: Their Management Practices and Research/Training Needs, 99-111. Bogor.

Rendig, V. V. \& Taylor, H. M. 1989. Principles of Soil-plant Interrelationships, 275 pp. McGraw-Hill, New York.

Saenger, P. 1982. Morphological, anatomical and reproductive adaptations of Australian mangroves, 153-191. In: Clough, B. F. (ed.), Mangrove Ecosystems in Australia. Australian Institute of Marine Science, Townswille, Australia.

Scholander, P. F., Dam, L. van \& Scholander, S. I. 1955. Gas exchange in the roots of mangroves. American Journal of Botany 42: 92-98.

Sena Gomes, A. R. and Kozlowski, T. T. 1980. Growth responses and adaptations of Fraxinus pennsylvanica seedlings to flooding. Plant Physiology 66: 267-271.

Tabuchi, R., Ogino, K., Aksornkoae, S. \& Sabhasri, S. 1983. Fine root amount of mangrove forest: A preliminary survey. Indian Journal of Plant Science 1: 31-40.

Toma, T., Nakamura, K., Patanaponpaiboon, P. \& Ogino, K. 1991. Effect of flooding 
water level and plant density on growth of pneumatophore of Avicennia marina. Tropics 1: $75-82$.

Received June 5, 1992

Accepted July 11, 1992

\section{JINTANA，二宮生夫，荻野和彦 土壤中の極端な低酸素濃度におけるRhizophora apiculata 実生苗の根系発達}

マングローブは高塩分濃度, 強酸性, 低酸素濃度などのストレスの下に生育している。これらの ストレスは互いに密接に関係しマングローブの生長に影響を与えているが，これまでマングロー ブのストレスに関する研究は高塩分濃度に集中していた。本研究は土壌中の低酸素濃度の影響を 明らかにする目的で, Rhizophora apiculata 実生苗を極端な低酸素濃度の土壤と通常の酸素濃度 の土壌で栽培し, それぞれの条件下での根系発達を比較した。

2 つの異なる樹齢の幼苗を愛媛大学農学部構内の温室において, 直径 $10.7 \mathrm{~cm}$, 深さ $42 \mathrm{~cm}$ の 円筒状のポットに植えつけた。10 個体は脹軸を新しく植えつけ，別の 10 個体は植栽後 80 日間 経過した幼苗である。ポットの縁までホーグランド培養液を満たした土㙵に, 低酸素濃度条件と 高酸素濃度条件を与えるため, 各樹㱓のポット 5 個づつにエアポンプで空気を送った。空気の流

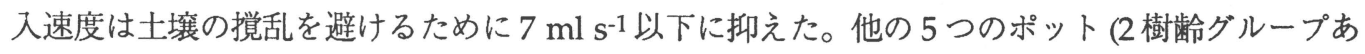
わせて 10 ポット) は低酸素濃度条件にするために無通気状態に保った。養分溶液は常にポットを 満たすように補充した。ポット内の深さ $15 \mathrm{~cm}$ に拀ける溶存酸素濃度を測定したところ, 無通気 条件では $0.6 \mathrm{mg} \mathrm{l}^{-1}$ 以下, 通気条件で 2.2-2.5 $\mathrm{mg} \mathrm{l}^{-1}$ を保っていた。各処理区で日中の純光合成速 度と葉の水ポテンシャルおよび夜間の暗呼吸速度を 1991 年 7 月 9 日に測定した。実験開始後 85 日目と 115 日目に幼苗を掘り取り現存量を測定した。掘り取った幼苗は丁寧に洗い, 主根と側根 の数を数えた。根を土壌表面から深さ $5 \mathrm{~cm}$ ごとに分け, 直径階別に重量を測定した。根の横断 面を顕微鏡で観察し，皮層の細胞㧍よび細胞間空隙の断面積を測定した。

無通気条件の栽培では，通気条件に比べて地上部，根とも乾重が減少した。根の乾重の減少割 合が 5 30\% であったのに対し, 地上部の滅少割合は 26〜38\% であった。しかし両者の T/R 率 には有意差は見られなかった。純光合成速度は無通気条件で高い值を示したが, 暗呼吸速度には 有意差が認められなかった。

無通気条件では通気条件に比べて, 側根の数が増加したが, 根の全長は短くなった。無通気条 件では根が比較的酸素濃度の高い土壤表層付近に多く分布し, 直径 $2 \mathrm{~mm}$ 以下の細根の占める 割合が多くなった。この細根の増加は側根の数の増加と密接に関係している。無通気条件では皮 層中の細胞間空隙率が増加した。低酸素濃度条件下で細胞間の空隙率が増加することは, 根系へ の酸素拡散にとって有利にはたらく。通気条件では無通気件にくらべて根の伸張速度が速く, 根 が深くまで貫入した。

以上のように土畩が極端な低酸素濃度におかれるとRhizophora apiculata 実生苗の根抢よび地 上部の生長は抑制される。しかし根系発達過程において, 比較的酸素濃度の高い表層付近に根を 分布させ, 側根や細根の割合が増加し, 根の全長を短くし, さらに皮層中の細胞間空隙率を増加 させ, 土畩中の低酸素条件に対する適応を獲得していることがわかった。 